\title{
STATE IMMUNITY STATUTES IN GONSTITUTIONAL PERSPECTIVE
}

Although the privilege against self-incrimination serves a vital
function in prohibiting a government from forcing a criminal
defendant to prove his own guilt, it frequently imposes undesirable
restrictions on the government's ability to acquire information
essential to make and enforce its public policies. To reduce the
impact of this limitation, states have enacted laws which immunize
a witness from subsequent incrimination in return for the witness'
testimony. With the extension of the fifth amendment to the
states, questions have arisen as to the constitutionality of such
state immunity statutes. This comment seeks to answer such
questions in light of current constitutional standards.

A. AN essential means of assuring "the effective functioning of government in an ordered society,"1 governments traditionally have been granted broad power to compel residents to testify concerning any affairs of which they have knowledge. ${ }^{2}$ Such authority is especially vital to the investigation and punishment of crimes, the proof of which might otherwise be impractical. ${ }^{3}$ The fundamental importance of this information-gathering power suggests that its exercise should be free and that the corresponding scope of the duty to testify should be broad. ${ }^{4}$ However, in the United States, this basic public right to information conflicts with another fundamental concept, namely, that a man may not be compelled to be a witness against himself in any criminal action. ${ }^{5}$ This privilege was constitutionally recognized by its inclusion in the fifth amendment ${ }^{6}$ of the Federal

\footnotetext{
${ }^{2}$ Murphy v. Waterfront Comm'n, 378 U.S. 52, 93-94 (1964) (White, J., concurring).

${ }^{2}$ See, e.g., Brown v. Walker, 161 U.S. 591 (1896). See generally 8 J. Wigmore, EviDENCE \$2192 (McNaughten rev. ed. 1961) [hereinafter cited as WIGMORE]; Wendel, Compulsory Immunity Legislation and the Fifth :Amendment Privilege: New Developments and New Confusion, 10 ST. Lovis U.L.J. 327 (1966).

${ }^{3}$ Murphy v. Waterfront Comm'n, 378 U.S. 52, 94 (1964) (White, J., concurring). The testimony of its citizens is a vital source of governmental information and is essential to effective regulation. 8 WIGMORE $\$ 2281$; Comment, The Federal Witness Immunity ficts in Theory and Practice: Treading the Constitutional Tight-rope, 72 YALE L.J. 1568 (1963) [hereinafter cited as Comment, 72 YALE L.J. 1568 (1963)].

- See generally Comment, 72 YALE L.J. 1568 (1963).

See Wendel, supra note 2; Note, 65 Colum. L. REv. 681 (1965). The privilege that "no man is bound to incriminate himself" in any court had its origins in the ecclesiastical courts and did not become established in the common-law courts of England until the middle of the seventeenth century. Even then, it existed for a number of years as little more than a bare rule of law and did not bloom in spirit until the early eighteenth century. Thus, it was never deemed to be the constitutional
} 
Constitution and in similar provisions of various state constitutions. ${ }^{7}$

In order to resolve the apparent conflict, both Congress and state legislatures have promulgated numerous statutes which allow governmental bodies to require witnesses to testify in exchange for the government's forfeiture of its right either to prosecute the witness for crimes disclosed or to use his testimony in subsequent prosecutions. ${ }^{8}$ Denominated immunity statutes and enacted at the cost of aborting the criminal law as to violations exposed, such legislation rests on the theory that if the state removes the basis for fearing selfincrimination, the witness can have no valid objection to giving his testimony. ${ }^{2}$ The validity of this theory was upheld by the Supreme Court in Counselman v. Hitchcock, ${ }^{10}$ a unanimous Court reasoning that legislation can replace a constitutional privilege only if "it is so broad as to have the same extent in scope and effect" as the privilege itself.11 As a result of the decision, a plethora of state ${ }^{12}$

landmark in England that the American constitution-makers esteemed it to be. 8 WIGMORE $§ 2250$.

The fifth amendment reads in pertinent part: "No person ... shall be compelled in any criminal case to be a witness against himself ..." U.S. Consr. amend. $V$. Any use of the term "fifth amendment" in this comment is intended to refer to the privilege against self-incrimination.

${ }^{7}$ See, e.g., CaL. Const. art. 1, §13; N.Y. Const. art. I, §6; N.C. Const. art. 1, §11; 8 WIGMORE $\$ 2252$ n.3.

svery state, without exception, has one or more immunity acts pertaining to various offenses or legislative investigations. For a recent listing of most of the states' witness immunity acts see 8 WIGMORE $\$ 2281$. The multitude of federal immunity statutes are listed in Comment, 72 Yale L.J. 1568, 1611 (1963).

- Wigmore justifies the immunity principle on these grounds: "Penalty is the creation of the law, not an inherent attribute in the act itself. . . The treasons and criminal hibels which filled English prisons centuries ago are now non-existent, though the same acts may be done today as then. The privilege protects only against legal consequences of conduct; hence, the legal consequences lacking, the privilege docs not exist for such conduct ..... A legislative provision, therefore, providing amnesty for an individual offender or class of offenders who shall disclose the facts of the offcnse upon inquiry is effective to remove the criminality of the offense, and the privilcge thereby ceases as to the person so disclosing." 8 WIGMORE $\$ 2281$, at 491 . See also Hale v. Henkel, 201 U.S. 43, 67 (1906).

It should be noted that if the danger of subsequent incrimination is removed by the running of the appropriate statute of limitations or like reasons, the fifth amendment cannot be claimed and therefore immunity need not be extended in order to compel testimony. See Singer, State Grants of Immunity-The Problem of Interstale Prosecution Prevention, 58 J. CRIM. L.C. \& P.S. 218, 220 (1967).

${ }^{10} 142$ U.S. 547 (1892). See notes 17-22 infra and accompanying text.

11142 U.S. at 585.

12 Since forty-eight states have constitutional provisions relating in form specifically to self-incrimination, see 8 WIGMORE $\$ 2252$, immunity statutes have enjoyed wide popularity on the state level, see $i d$. $\$ 2281$. However, because these state constitutional privileges vary from state to state, an immunity statute which is constitutionally sufficient in one state is not necessarily adequate in another. This disparity 
and federal ${ }^{13}$ immunity statutes were adopted, some of which granted immunity from prosecution to the testifying witness, while others merely provided immunity from the use of such testimony in subsequent criminal actions. Because of these differing degrees of immunity, substantial questions have arisen as to their constitutionality under the Counselman standard. Furthermore, two recent Supreme Court decisions-Malloy v. Hogan ${ }^{14}$ and Murphy v. Waterfront Commission ${ }^{15}$-raise additional questions of the continued efficacy of the Counselman rule ${ }^{16}$ and of the constitutional validity of immunity statutes which cannot or do not immunize the witness from prosecution by another jurisdiction. This comment seeks to resolve these questions with specific reference to state immunity laws.

\section{The Constitutional Standards}

\section{Intrajurisdictional Immunity}

The first constitutional challenge to an immunity statute was presented by Counselman $v$. Hitchcock, ${ }^{17}$ a case arising under a

led to much variation in the statutes among the several states. Compare State v. Quarles, 13 Ark. 307 (1853) (interpreting art. 2, §11, of the Arkansas constitution of 1836), with Henry Emery's Case, 107 Mass. 172 (1871) (interpreting article 12 of the Declaration of Rights in the 1780 constitution of Massachusetts).

Not only does great variety exist among the statutes of different states, great variety also exists among the several statutes of each state as well. Each state has many statutes, most of which were designed at different times, to cope with different crimes, and were tailored for use by different bodies. Thus, there is no core statute in each state from which the rest have been fashioned. See generally Note, 20 RutGers I. REv. 336, 342-43 (1966).

${ }^{13} \mathrm{Mr}$. Justice White, concurring in Murphy v. Waterfront Comm'n, 378 U.S. 54, 92 (1964), noted that Congress has enacted more than forty immunity statutes. Id. at 94. Furthermore, in Ullmann v. United States, 350 U.S. 422 (1956), the Court declared that immunity statutes have "become part of our constitutional fabric." Id. at 438. Actually the growth of immunity statutes on the federal level resulted not directly from Counselman, which had invalidated the Immunity Act of 1868, ch. 13, 15 Stat. 37, on the ground that it was not co-extensive with the privilege; rather, it followed the Court's decision in Brown v. Walker, 161 U.S. 591 (1896), which upheld the Immunity Act of 1893 , ch. 83,27 Stat. 443 , as fully accomplishing the object of the privilege. 161 U.S. at 610 ; see Wendel, supra note 2 , at $342,346-48$.

14378 U.S. 1 (1964).

10378 U.S. 52 (1964).

${ }^{10}$ Malloy and Murphy have spawned numerous conflicting interpretations regarding the apphicable standard by which the constitutionality of an immunity statute is to be determined. See In re Bonanno, 52 Misc.2d 748, 277 N.Y.S.2d 909 (Sup. Ct. 1966). Sobel, The Privilege Against Self-Incrimination "Federalized" 31 BRookLyN L. REv. 1 (1964); Wendel, supra note 2; Comment, Federalism and the Fifth: Configurations of Grants of Immunity, 12 U.C.L.A.L. REv. 561 (1965) [hereinafter cited as Comment, 12 U.C.L.A.L. REv. 561 (1965)]; Note, 33 FordhaM L. Rev. 77 (1964); Note, 1 GA. B.J. 366 (1965); Note, 61 Nw. U.X. REv. 654 (1966); Note, 10 N.Y.L.F. 627 (1964); Note, 20 Rutgers L. Rev. 336 (1966); Note, 73 Yale L.J. 1491 (1964).

${ }^{17} 142$ U.S. 547 (1892). 
federal immunity statute which precluded the use of compelled testimony in any subsequent federal criminal action against the witness..$^{18}$ After being promised such immunity, defendant Counselman refused to answer questions concerning violations of the Interstate Commerce Act on the ground that his answers might tend to incriminate him, and was convicted of contempt of court for his refusal. ${ }^{10}$ In reversing the conviction, the Supreme Court enunciated the general standard that immunity legislation, to be valid under the fifth amendment, must afford the witness the same protection that he would have received by asserting his privilege against self-incrimination..$^{20}$ The federal immunity statute in question did not provide such coextensive protection, for it did not preclude the Government from using defendant's testimony as a means of discovering other evidence which could form the basis of a criminal prosecution. ${ }^{21}$ In the Court's view, the only type of immunity statute which would afford co-extensive protection was one which granted absolute immunity from subsequent federal prosecution for offenses disclosed by the inquiring jurisdiction. ${ }^{22}$

Because of state constitutional provisions protecting the privilege against self-incrimination, many states enacted legislation at an early date immunizing witnesses compelled to testify either from prosecution for crimes disclosed or from the use of testimony in subsequent state prosecutions. However, Counselman was not applicable to such state laws because, at the time of that decision, its constitutional basis-the fifth amendment-had not been adopted as part

${ }^{18}$ REv. STAT. $\$ 860$ (1875) provided as follows: "No pleading of a party, nor any discovery or evidence obtained from a party or witness by means of a judicial proceeding . ..., shall be given in evidence, or in any manner used against him ...., in any court of the United States in any criminal proceeding, or for the enforcement of any penalty or forfeiture ...."

10142 U.S. at 548-53. The District Court for the Northern District of Illinois had found Counselman to be in contempt of court, whereupon he filed in the circuit court of the United States for that district a petition for a writ of habeas corpus. When the circuit court affirmed the order of the district court, In re Counselman, 44 F. 268 (C.C.N.D. Ill. 1890), Counselman appealed to the Supreme Court.

${ }^{20} 142$ U.S. at 585.

$22 I d$. at $564-65$.

${ }^{22} I d$. at 586. The rule of absolute immunity from prosecution frequently has been referred to as the Counselman standard. See, e.g., Note, 61 Nw. U.L. REv. 654, 659 (1966); Comment, 12 U.C.L.A.L. REv. 561, 575-78 (1965). While the facts of Counselman necessarily restrict the applicability of the standard to a federal grant of immunity when the threatened prosecution is an intrajurisdictional one by the federal government, the Court's language would seemingly require application of this absolute standard to any jurisdiction to which the fifth amendment is also applicable. 
of the due process clause of the fourteenth amendment. ${ }^{23}$ However, in 1964 the Supreme Court decided Malloy $v$. Hogan. ${ }^{24}$ Defendant Malloy had been adjudged in contempt of court for refusing to answer questions during a Connecticut gambling investigation. ${ }^{25}$ In reversing the conviction, the Supreme Court first ruled that the due process clause incorporated the fifth amendment's protection against self-incrimination, thereby applying it to the states. ${ }^{28}$ As a consequence, the Court asserted that "the same standards must determine whether an accused's silence in either a federal or state proceeding is justified."27 Finding that Connecticut's protection was inadequate as compared with the federal standard, the Court held that the defendant's federal privilege had been infringed and reversed his conviction. The Malloy decision said nothing about the validity of state immunity statutes. However, it is evident that, by applying the fifth amendment's federal standards to the states, Malloy made the Counselman standard for federal immunity legislation determinative also of the constitutionality of state immunity statutes.

\section{Extrajurisdictional Immunity}

The Counselman view that a valid immunity statute must prohibit the government which compels testimony from instituting subsequent criminal prosecution against the witness is, in essence, an intrajurisdictional limitation. However, Counselman failed to consider whether a statute which did not proscribe prosecution by a

28 The bounds of the constitutional privilege in the interval from 1892 until 1964 were further delineated by three Supreme Court decisions. First, Twining v. New Jersey, 211 U.S. 78 (1908), held that the fifth amendment was not applicable to the states through the fourteenth amendment. In United States v. Murdock, 284 U.S. 141 (1931), the Court found that the fifth amendment did not require that a federal immunity statute grant immunity from a subsequent state prosecution. Finally, the introduction of testimony given under a state grant of immunity was allowed in a federal court in Feldman v. United States, 322 U.S. 487 (1944).

24378 U.S. 1 (1964).

25 Petitioner applied for a writ of habeas corpus. His application was denied by the Superior Court, and the Connecticut Supreme Court of Errors affirmed. Malloy v. Hogan, 150 Conn. 220, 187 A.2d 744 (1963). Subsequently, the United States Supreme Court granted certiorari. 373 U.S. 948 (1963).

20378 U.S. at 3.

${ }^{27}$ Id. at 11 (emphasis added). By the phrase "the same standards," the Malloy Court was referring to the federal standard enunciated in Hoffman v. United States, 341 U.S. 479, 486 (1951), where the Court lad said: "The privilege afforded not only extends to answers that would in themselves support a conviction ... but likewise embraces those which would furnish a link in the chain of evidence needed to prosecute ...." 
different jurisdiction would satisfy the constitutional standard that the immunity conferred must be co-extensive with the fifth amendment privilege. Nevertheless, four years after Counselman, the issue of whether a valid immunity statute must confer extrajurisdictional immunity was confronted in Brown v. Walker. ${ }^{28}$ Defendant Brown was convicted of contempt for his refusal to answer the questions of a federal grand jury, even though he had been granted immunity under a federal statute which provided that "no person shall be prosecuted ... for or on account of any transaction, matter or thing, concerning which he may testify ...."20 The Supreme Court upheld the conviction by broadly construing the federal statute to comprehend immunity from prosecution by both federal and state authorities. ${ }^{30}$ Such immunity, the Court held, was effective as a defense to state prosecution because the federal statute upon which it was based took priority over any conflicting state law by virtue of the supremacy clause of the Constitution. ${ }^{31}$

The reasoning of Brown was employed by the Court in 1954 to reverse a state conviction of a witness based on testimony compelled under a federal immunity statute which precluded only the use of such testimony in any court. ${ }^{32}$ Two years later, the Brown decision was expressly reaffirmed in Ullmann $v$. United States, ${ }^{33}$ the Court

28161 U.S. 591 (1896).

${ }^{29}$ Act of Feb. 11, 1893, ch. 83, 27 Stat. 443.

${ }^{30}$ Since the statute in question failed to specify that it applied to any particular court, the Brown Court was able to assert that Congress intended it to apply to state as well as federal courts. Thus the Court stated: "[T] he immunity extends to any transaction, matter or thing concerning which he may testify, which clearly indicates that the immunity is intended to be general, and to be applicable whenever and in whatever court such prosecution may be had." 161 U.S. at 608. Congressional power to prohibit the states from prosecuting a witness federally immunized under the statute in question apparently emanated from the commerce clause, plus the necessary and proper clause. Such an interpretation of Brown was given by Mr. Justice Frankfurter in Ullmann v. United States, 350 U.S. 422, 436 (1956). See Adams v. Maryland, 347 U.S. 179, 183 (1954). Another basis for such federal power is the combination of tlie implied power to provide for the national defense and the necessary and proper clause. See Ullmann v. United States, supra at 435-36.

${ }^{31} 161$ U.S. at 606-07. The Brown Court refuted other arguments presented by tlie defendant. Even assuming the possible danger of subsequent extrajurisdictional prosecutions, the Court dismissed it as a "danger of an imaginary and unsubstantial character," not worthy of protection under the fifth amendment. Id. at 608. Furthermore, the Court pointed out that the fifth amendment did not protect the defendant from the "annoyance and expense" of having a prosecution brought against him. Thus, if the federal immunty statute afforded such a defendant a sound defense to the charge, it afforded adequate protection. Id.

${ }^{35}$ Adams v. Maryland, 347 U.S. 179 (1954).

${ }^{33} 350$ U.S. 422, 439 (1956). 
construing a federal immunity statute similar to that in Brown as proscribing subsequent prosecutions in either federal or state courts. ${ }^{34}$ Thus, by such broad construction of immunity legislation, plus the application of the supremacy clause, the Court fashioned extrajudicial immunity for a federal witness against either prosecution or use of his testimony against him in criminal actions by the states. It was thereby able to sustain federal immunity statutes under the co-extensiveness standard of Counselman.

Although Congress, under the Brown rationale, could effectively prohibit state prosecution of witnesses compelled to testify by the federal government, that method of obviating the fear of subsequent prosecution by another jurisdiction was inherently unavailable to the states. States had neither the power to proscribe prosecutions outside their jurisdictions nor a supremacy clause to give their statutes priority over those of other jurisdictions. ${ }^{35}$ Thus, in spite of its characterization as "illusory" in Brown, the fear of prosecution by another jurisdiction was a real one to witnesses compelled to testify by the states. ${ }^{37}$

The Supreme Court specifically recognized the genuineness of this fear in Murphy $v$. Waterfront Commission, ${ }^{38}$ decided on the same day as Malloy v. Hogan. ${ }^{39}$ After being granted immunity from prosecution by New York and New Jersey, 40 defendants refused to testify in a bi-state investigation of work stoppages on the ground that their testimony might subject them to subsequent federal prosecution. Expressly recognizing this danger, the Court ruled that the fifth amendment "protects a state witness against incrimination under federal as well as state law and a federal witness against incrimination under state as well as federal law."41 Applying that holding to state immunity statutes, the Court declared that:

\footnotetext{
sc Id. at 436 .

${ }^{35}$ See Knapp v. Schweitzer, 357 U.S. 371, 375, 378-80 (1958); Jack v. Kansas, 199 U.S. 372,380 (1905); 8 WIGMORE $\S 2258$.

${ }^{30}$ See note 31 supra.

${ }^{87}$ For a listing of states which recognized the genuineness of the fear of subsequent prosecution by a jurisdiction other than the one compelling the testimony see 8 WIGMORE $\$ 2258$ n.2.

${ }^{38} 378$ U.S. 52 (1964).

${ }^{30} 378$ U.S. 1 (1964). See notes 24-27 supra and accompanying text.

10 Immunity from prosecution was granted by both states since the Waterfront Commission of New York Harbor is a bi-state body established under an interstate compact. See 378 U.S. at 53 n.2.

aId. at 78 ,
} 
a state witness may not be compelled to give testimony which may be incriminating under federal law unless the compelled testimony and its fruits cannot be used in any manner by federal officials in connection with a criminal prosecution against him. ${ }^{\mathbf{4 2}}$

Unfortunately, no state has the power to grant a witness the required immunity from the use of his testimony in a federal prosecution. Nevertheless, to secure the states' right to compel testimony under immunity legislation, the Court held that the federal government would not be allowed to use either a witness's testimony or the fruits thereof against him in a federal prosecution, if such testimony had been compelled under a state grant of immunity.43 The holding seemed to be founded on the fifth amendment.44 Thus, the fifth amendment itself was interpreted to provide extrajurisdictional immunity for state-compelled witnesses fearing subsequent federal prosecution. Therefore, the Court was able to conclude that a state immunity statute, in combination with the fifth amendment's own restriction on the use of state-compelled testimony by the federal government, ${ }^{45}$ provided protection co-extensive with the privilege of self-incrimination. Conversely, since the fifth amendment now applies to the states, this rationale provides further support for prohibiting a state from using evidence compelled under a federal immunity statute in its own criminal prosecution of the witness. ${ }^{40}$

\footnotetext{
$1 d$. at 79 .

${ }^{4} I d$.

" Courts and commentators have argued over the basis of the Murphy rulc, some asserting that the Court's power to promulgate a rule prohibiting the federal courts from using state-compelled testimony rested on its authority to supervise the federal court system, see 378 U.S. at 91-92 (Harlan, J., concurring), others arguing that such power arises out of the fifth amendment, Comment, 12 U.C.L.A.L. REv. 561, 578-80 (1966). In view of the general manner in which the Court stated the question presented by the case-"whether one jurisdiction within our federal structure may compel a witness, whom it has immunized from prosecution under its laws, to give testimony which might then be used to convict him of a crime against another such jurisdiction," 378 U.S. at 53, and in light of its pronouncement that "in order to implement this constitutional rule . . . the Federal Government must be prohibited from making any such use of compelled testimony ....." id. at 79 (emphasis added), it is more reasonable to consider the fifth amendment the true basis for the rule.

15 If the Court had not interpreted the fifth amendment as probibiting the use of state-compelled testimony in federal courts, state immunity legislation, and the power of the states to compel needed information, would have been destroyed. This follows from the fact that the states lack the power to restrict either the federal government or other states from bringing criminal prosecutions against the compelled witness. Sec note 35 supra and accompanying text.

${ }^{16}$ See notes 28-34 supra and accompanying text for a discussion of how a broad construction of federal immunity statutes, plus the application of the federal supremacy clause, may be employed to prohibit state use of federally-compelled testinony.
} 
One further fear of incrimination which could not be removed by state immunity grants alone is that compelled testimony might be used in the prosecution of the witness by sister states. The Murphy decision made no specific reference to this possibility. However, in view of the Court's statement of the issue in terms of whether "one jurisdiction within our federal structure" might compel a witness to give testimony which might be used against him in "another such jurisdiction," 47 it is reasonable to assume that the Murphy holding was implicitly intended to apply between sister states. As a result, once a state has compelled testimony upon a grant of immunity, the fifth amendment would prevent a sister state from using such testimony or its fruits in a criminal action against the witness. Thus, Counselman's co-extensiveness standard would be satisfied.

\section{Current Constitutional Standards}

The constitutional standards for judging the validity of federal and state immunity statutes may now be set forth as follows:

(a) Counselman test: Both the federal government and-as a result of the application of the fifth amendment to the states-the states must provide absolute immunity from prosecution for crimes disclosed in order validly to compel the testimony of a witness fearing self-incrimination.

(b) Murphy test: Both the federal government and the states may compel the testimony of the witness, even though the witness may fear incrimination in another jurisdiction, because the fifth amendment itself now prohibits another jurisdiction from using such compelled evidence or its fruits in a prosecution against the witness. A reading of the Supreme Court's decisions indicates that if the standards are complied with, federal and state immunity statutes will afford protection co-extensive with the privilege against self-incrimination itself, as required in Counselman.

As stated, the standards present an obvious inconsistency; i.e., an intrajurisdictional immunity statute must provide a higher degree of protection than need be given extrajudicially. Several theories have been offered to explain why the Court has permitted two dissimilar standards to exist simultaneously. For example, it has been asserted that the creation of the dual standard was a result of the Court's in-

${ }^{47} 378$ U.S. at 53. 
advertence. ${ }^{48}$ The Court's failure to overrule Counselman in the Murphy decision is the primary foundation for this theory. However, both the fact that Murphy did not present the intrajurisdictional immunity question, thereby not necessitating the overruling of Counselman, and its express reliance on the co-extensiveness standards of Counselman while ignoring that case's "absolute immunity from prosecution" rule lessen the plausibility of the Court's inadvertence as a sound explanation. A more reasonable rationale is that the Court, adhering to Counselman's co-extensiveness standard, deemed it unnecessary to grant immunity from prosecution in order to give the same protection to a witness as he would have by asserting his privilege against self-incrimination. ${ }^{40}$ Underlying this finding is the Court's elimination of the fear of the use of either the testimony itself or its fruits in subsequent proceedings, a fear the Murphy Court viewed as the basis for holding the immunity statute in Counselman invalid. With this fear removed, the Court could implicitly conclude that it no longer needed to adhere to the Counselman requirement of immunity from prosecution. While this analysis does not explain why the Court did not overrule the language in Counselman requiring immunity from prosecution, it is consistent with the opinions of both the majority and Mr. Justice White. However, since the Court has neither overruled one of the standards nor explained why there should be a difference, this comment will examine the constitutionality of state immunity statutes on the assumption that both standards must still be met.

\section{State IMMUNITy STATUTES ${ }^{50}$}

Since the fifth amendment did not limit state action until 1964, states were under no federal imperative to enact immunity legislation in order to compel needed testimony over a self-incrimination

\footnotetext{
18 See Wendel, supra note 2 , at 370 .

${ }^{*}$ See Comment, 12 U.C.L.A.L. REv. 561, 577-85 (1965).

${ }^{50}$ Depending on the particular statutory language, state.granted immunity attaches to a witness's testimony either automatically, see, e.g., Mrcr. Comp. Laws \$462.27 (1948); N.C. GEN. STAT. $\$ 49-6$ (1950), or upon assertion, or claim, of a fifth amendment or state constitutional privilege against self-incrimination, see, e.g., KY, REv, STAT. $\$ 199.430$ (1962); MINN. STAT. $\$ 80.22$ (1961). Claim statutes, on the one hand, encompass only minimum constitutional requirements. Absent invocation of the privilege, the witness may be deemed to have waived this right, Vajtauer v. Commissioner, 273 U.S. 103, 113 (1927); and since any testimony volunteered is without constitutional protection, immunity need not be ensured. On the other hand, once specified condi-
} 
objection. However, the presence of similar privileges against selfincrimination in most state constitutions required state legislatures desiring to compel testimony to enact statutes immunizing witnesses from subsequent intrajurisdictional incrimination. Because most states adopted, on an ad hoc basis, immunity laws to secure specific information for such limited purposes as gambling investigations or election laws supervision, a multitude of immunity statutes are now in force. ${ }^{61}$ In evaluating the validity and wisdom of these statutes, it is therefore necessary to consider the many distinctions which they suggest: intrajurisdictional versus extrajurisdictional protection; immunity from prosecution versus immunity from use of testimony;

tions-usually that testimony be under oath and pursuant to a subpoena, see, e.g., MiNN. STAT. $\$ 297.09$ (1961)-are met, automatic statutes extend immunity to all incriminating utterances. Since they offer greater protection than do claim statutes which meet constitutional standards, there is no question of their validity.

Although a number of statutes expressly require a claim or use language, such as "in spite of his objection," which clearly renders a claim prerequisite to immunity, see, e.g., Mass. GeN. LAws ANN. ch. I50A, \$7 (1965); N.D. CENT. Code \$ 38-08-12 (1960), the necessity of a witness's act to invoke statutory protection is not always clear. In fact, the most usual phraseology completely avoids reference to the requisite procedure precedent to its applicability: "No person shall be excused from testifying or from producing any books, accounts, maps, papers or documents in any action or proceeding, based upon or growing out of any alleged violation of any of the provisions of this act, on the ground or for the reason that the testimony or evidence ... required from him, may tend to incriminate him or subject him to penalty or forfeiture ...." KAN. GEN. STAT. ANN. \$66.I14 (1964). Interpreting language very similar to this, an Arizona court concluded that the protection was self-executing. State v. Chitwood, 73 Ariz. 314, 240 P.2d 1202 (1952). A Wisconsin court, on the other liand, reasoned that the intent of the legislature must liave been to grant no greater immunity than was constitutionally compelled and that, therefore, absent a claim, incriminating statements could be validly invoked in subsequent prosecutions. State v. Davidson, 242 Wis. 406, 8 N.W.2d 275 (1943). This latter rationale would be acceptable were it not for the fact that many statutes employing language substantially identical with that of the Kansas statute expressly require a claim, while similar statutes within the same state have no such requirement, thus rendering inconclusive the issue of legislative intent. Compare ARIz. REv. STAT. ANN. $\$ 44-1824$ (1956), with ARIz. REv. STAT. ANN. \$27-518 (1956); and compare N.M. STAT. ANN. \$59-4-8 (1960), with N.M. Stat. ANN. \$64-27-80 (1960). See also United States v. Monia, 317 U.S. 424, 429-30 (1943).

It might be stated that statutes specifying that a witness may be "required," see, e.g., Miss. CodE ANN. \$9028-41 (1956), or "compelled," see, e.g., GA. CoDE ANN. \$ 93-506 (1958), to testify generally warrant classification as claim provisions. A Florida court, however, has interpreted a provision that "any person ... may be compelled to . . . testify" as requiring no claim of a privilege or resistance by a witness. State ex rel. Marshall v. Petteway, 121 Fla. 822, 164 So. 872 (1936). Perhaps guidelines for classification are revealed by the observation that as far as federal statutes are concerned, few offering automatic protection have been passed subsequent to 1930, and almost all of this variety have required that the witness appear under oath and subject to a subpoena. Sce Comment, 72 Yale L.J. 1568, 1590 (1963).

Ex For a listing of state immunity statute citations, plus a description of the purpose for which immunity may be granted, see 8 WIGMORE $\$ 2281$. 
criminal immunity versus civil immunity; immunity from incrimination for all crimes disclosed versus immunity from incrimination for only those crimes under investigation; and the conditions upon which the grant of immunity depends.

\section{Varieties of Intrajurisdictional Immunity Grants}

Immunity from prosecution. While all state immunity statutes purport to protect the witness from intrajurisdictional incrimination, 52 two basic kinds of insulation have been utilized: immunity from prosecution and immunity from the use of the compelled testimony. Although initially the Counselman immunity-from-prosecution test did not have to be met by the states, most were influenced by the Supreme Court's ruling and therefore adopted statutes similar to that of Wyoming, which allows the state to compel testimony before a public utilities commission in spite of a self-incrimination objection:

$[\mathrm{N}] \mathrm{o}$ person having so testified shall be prosecuted or subjected to any penalty or forfeiture for or on account of any transaction, matter or thing concerning which he may have testified or produced any documentary evidence; provided, that no person so testifying shall be exempt from prosecution or punishment for perjury in so testifying. 53

Such legislation precludes the compelling state from subsequently bringing a criminal prosecution against the witness for any crimes disclosed under the compulsion of the statute. ${ }^{54}$ All states which

ca A discussion of the few statutes which attempt to protect the witness from extrajurisdictional incrimination may be found in the text accompanying notes 77-79 infra.

¿s Wyo. STAT. ANN. $\$ 37-35$ (1959) (emphasis added). Other state public utilities statutes present variations on the language of the statute quoted in the text. Tlius, PA. STAT. ANN. tit. 66, §1402 (1959) provides that "no person shall be prosecuted, punished or subjected to any forfeiture or penalty for or on account of any act, transaction, matter, or thing concerning which he shall have been compelled ... to testify ...." CaL. Pub. UTu. Code $\$ 1795$ (West 1956) reads: "[N]o person shall be prosecuted, punished, or subjected to any penalty or forfeiture for or on account of any transaction, matter or thing concerning which, under oath, he has testified ....."

os The witness against whom prosecution is precluded by the immunity statute must be a natural person, and not a corporation. See notes 110-14 infra and accom. panying text. California makes this crystal clear: "Nothing herein contained shall be construed as in any manner giving to any public utility immunity of any kind." CAL. PUB. UTIL. CODE $\$ 1795$ (West 1956). The reason why immunity is available only to individuals is that only natural persons have the benefit of the privilege against self-incrimination. Hale v. Henke1, 201 U.S. 43, 74-75 (1906). There being no privilege for corporate persons, the state does not need to offer immunity in exchange for testimony. It may compel the corporate person to testify without it. 
have construed such immunity-from-prosecution statutes are unanimous in holding that the protection conferred is co-extensive with the self-incrimination provisions of their state constitutions. ${ }^{55}$ Furthermore, even though the fifth amendment is now applicable to the states, it is evident that such immunity provisions meet the broad Counselman test by affording "absolute immunity against future prosecution for the offense to which the question relates."56

Specified crimes. Realizing that a general immunity-from-prosecution provision completely aborts the criminal law process with respect to the witness compelled thereunder to testify, several states have enacted statutes which attempt to limit the crimes for which immunity from prosecution may be given. For example, an Alaska statute authorizing compulsion of testimony in a gambling investigation specifies that "a prosecution may not afterwards be brought against the witness for the offense of gambling or the gambling transaction concerning which he testified."'57 Such limited immunity grants implicitly permit prosecution for other crimes on the basis of compelled testimony. State courts, determining the validity of such statutes under state constitutions, have not utilized a uniform rule. Rather, they have held testimony validly compelled and immunity constitutionally adequate under such statutes if there is no showing that the witness will be exposed to prosecution for "unrelated offenses" as a result of his testimony..$^{58}$ However, an adequate show-

Furthermore, it is unanimously agreed that a witness is only accorded immunity under immunity laws from prosecution based on his answers to questions which he was compelled to give. No immunity need be extended if the witness voluntarily responded to the question. See State v. Backstrom, 117 Kan. 111, 230 P. 306 (1924); State v. Saginaw, 124 Mont. 225, 220 P.2d 1021 (1950). See generally 8 WrGmorE $\S 2282$.

w For a listing of state cases in which immunity-from-prosecution statutes have been held constitutionally adequate see Annot., 118 A.L.R. 602, 619-24 (1939), and Annot., 53 A.L.R.2d 1030, 1033-40 (1957).

to Counselman v. Hitchcock, 142 U.S. 547, 586 (1892). In Brown v. Walker, I61 U.S. 591 (1896), the Supreme Court held a federal immunity-from-prosecution statute valid over a fifth amendment objection. See notes 28-31 supra and accompanying text. Similar statutes have subsequently been approved by the Court in Ullmann v. United States, 350 U.S. 422 (1956). Since most state immunity-from-prosecution statutes are similar to the federal statutes tested, it is reasonable to assume that they too would be deemed constitutionally acceptable under the Counselman standard.

E7 ALASKa StaT. $\$ 11.60 .150$ (1962). A more generalized version of the immunityfrom-specific-prosecution statutes is ORE. REv. STAT. $\$ 167.520$ (1965): "No indictment or prosecution shall afterwards be brought against him for the particular offense concerning which he testified as a witness."

${ }^{\circ}$ See Brown v. State, 233 Md. 288, 196 A.2d 614 (1964); Barbuto v. Silver, 19 Misc. 
ing of such a danger would seem to preclude the forcing of testimony on the basis of such a limited immunity statute because the witness would still retain a self-incrimination objection against such compulsion. ${ }^{59}$ This follows from the rule that a witness's privilege against self-incrimination is never destroyed by an immunity statute unless that statute, as applied, provides protection co-extensive with the privilege itself. The flexible approach of the state courts in dealing with the validity of immunity-from-specific-prosecution statutes merits adoption by the federal courts under the Counselman test. Under either state or federal tests, it is believed that the investigating body should be empowered to determine the adequacy of the danger of the witness's exposure to prosecutions for non-immunized offenses. Otherwise, the witness could capriciously refuse to testify, and thereby frustrate the legislative purpose underlying the immunity statute.

Immunity from use. In contrast to immunity-from-prosecution laws, a number of statutes merely preclude the subsequent use of compelled testimony in criminal prosecutions against the witness. Thus, if a state such as California compels a witness to testify in an investigation of legislative bribery, that witness's "testimony shall not afterwards be used against him in any judicial proceeding." Such a statute would seemingly permit the state to prosecute the witness for crimes he was forced to disclose, but would prohibit the introduction of his previously-given testimony. Where the language of the state constitutional provision against self-incrimination is similar to the fifth amendment's, ${ }^{61}$ many state courts have held

2d 149, 186 N.Y.S.2d 1018 (Sup. Ct. 1959); State v. Hennessey, 195 Ore. 355, 245 P.2d 875 (1952).

${ }^{50}$ See Overman v. State, 194 Ind. 483, 143 N.E. 604 (1924); Doyle v. Hofstader, 257 N.Y. 244, 177 N.E. 489 (1931); cf. State ex rel. Mitchell v. Kelly, 71 So. 2d 887 (Fla. 1954). An "adequate showing" of danger may be made without revealing the substance of the evidence which is incriminating. For instance, a witness may show to the court that he may be implicated if he is required to disclose his acquaintance with other known defendants. Since this may form a link in the chain of evidence against him for a non-immunized crime, it would constitute an "adequate showing" of danger.

${ }^{\circ}$ Cal. Gov'r Code $\$ 9054$ (West 1966); see, e.g., ARIz. REv. Stat. ANN. \$ 13-384 (1956); Conn. Gen. Stat. Rev. \$12-445 (1958); Fla. Star. $\$ 350.60$ (1965); KaN. Stat ANN. \$25-1426 (1964); N.C. GEN. STAT. \$14-38 (1958). A variation of the immunityfrom-use statute is one which requires that compelled testimony not be used"directly or indirectly"-against the witness. See, e.g., ArA. CoDE tit. 29, § 113 (1958) ("no testimony .... shall in any manner ... . be used as evidence, directly or indirectly ....”); N.H. REv. Star. ANn. \$15:7 (1955) ("no testimony . . . shall be used directly or indirectly as evidence....').

-1 Most state constitutional provisions against self-incrimination contain the same 
immunity-from-use statutes constitutionally inadequate. ${ }^{62}$ Such legislation has not been deemed co-extensive with the state's privilege against self-incrimination because it does not prohibit using the testimony as a "lead" to other incriminating evidence, known as "fruit," which may be admissible to convict the witness. ${ }^{63}$ Furthermore, since the federal constitutional standard stated in Counselman now applies to state law, it is clear that immunity-from-use statutes are also invalid under the fifth amendment. ${ }^{84}$

It has been argued that the Supreme Court's adoption of a different standard in the Murphy case was an implicit rejection of the broad Counselman standard. Therefore, since there is no reason why a different standard should apply to intrajurisdictional incrimination than should apply in the extrajurisdictional setting, the Counselman immunity-from-prosecution test should be discarded. ${ }^{65}$ Should this argument be approved in the future, state immunityfrom-use statutes would still suffer the constitutional infirmity of permitting the "fruits" of the witness's testimony to be used against him. To avert this, state courts and legislatures could easily interpret the prohibition against use to encompass not only the testimony itself but also the "fruits" of the testimony. Such a construction is especially suggested by statutes which preclude the use of testimony, "directly or indirectly," against the witness. ${ }^{68}$

The "compromise" statute. Some states have attempted to strike

or similar wording as does the fifth amendment. However, at least two states, Iowa and New Jersey, have no specific constitutional prohibition against self-incrimination. A New Jersey statute stating that compelled testimony shall not be used against the witness has been upheld on the grounds that it provided protection as complete as would be provided by the common law privilege against self-incrimination, which was part of New Jersey law. See In re vince, 2 N.J. 433, 67 A.2d 141 (1949). In Iowa, the privilege against self-incrimination has been read into the state constitution's due process clause. State v. Height, 117 Iowa 650, 91 N.W. 935 (1902). In Koonck v. Cooney, 244 Iowa 153, 55 N.W.2d 269 (1952), the Iowa court held that the state due process provision was not violated by the compelling of testimony under a statute which stated that no witness compelled to testify would be prosecuted "for any crime which such testimony or evidence tends to prove or to which the same relates." Id. at 155,55 N.W.2d at 271.

${ }^{02}$ See, e.g., People ex rel. Lewisohn v. O'Brien, 176 N.Y. 253, 68 N.E. 353 (1903); State ex rel. North v. Kirtley, 327 S.W.2d 166 (Mo. 1959); Commonwealth v. Frank, 159 Pa. Super. 271, 48 A.2d 10 (1946); Dendy v. Wilson, 142 Tex. 460, 179 S.W.2d 269 (1944).

${ }^{08}$ See, e.g., In re Watson, 293 Mich. 263, 291 N.W. 652 (1940); cf. People v. Nowack, 180 Misc. 100, 40 N.Y.S.2d 131 (Sup. Ct. 1943).

os See notes 17-27 supra and accompanying text.

or See Comment, 12 U.C.L.A.L. REv. 561, 579-85 (1965).

${ }^{\circ}$ See note 60 supra. 
a compromise between complete immunity from prosecution for all crimes disclosed and a limited immunity from prosecution for specified crimes. Such "compromise" statutes generally immunize the witness from prosecution "for the offense with reference to which his testimony was given,"67 and, in addition, preclude the use of any testimony he may be compelled to give in "any prosecution or proceeding . . . against the person so testifying."68 Adopting a test similar to the one applied to immunity-from-specific-prosecution statutes, ${ }^{69}$ it would seem that the "compromise" statute would be unconstitutional as applied only if there was an adequate showing of danger of exposure to prosecution for other crimes. If such a showing were made, complete immunity could not be achieved under the Counselman test since the "fruits" of the testimony could subsequently lead to a prosecution for crimes for which the statute provides no immunity. If the compelled testimony itself were not used in such prosecution, the statute's immunity-from-use provision would provide no additional protection. On the other hand, if the Murphy test were adopted intrajurisdictionally, and the term "testimony" were interpreted to include both the testimony and its "fruits," then the statute would be constitutionally valid. If valid, it would seem a commendable attempt to balance the need to protect the witness with the danger of paralyzing the enforcement of criminal laws.

Immunity from civil liability. While the fifth amendment only requires immunity from criminal prosecution, ${ }^{70}$ some state statutes

${ }^{o 7}$ E.g., Colo. Rev. Stat. AnN. \$49-21-3 (1963).

${ }^{68}$ Id. (emphasis added); see, e.g., Ala. Code tit. $9, \S 39$ (1959); N.C. Gen. StAT. $\S 15-99$ (1965); VA. CODE ANN. \$4-94 (1950).

${ }^{\circ}$ See notes 58-59 supra and accompanying text.

${ }^{70} 8$ WIGMORE $\$ 2254$. While it is clear that only penalties are proscribed by a grant of immunity, "penalty" is not generally susceptible of precise definition. In Bognton v. State, 75 So. 2d 211 (Fla. 1954), the state sought to abate a bookmaking nuisance and requested answers to interrogatories which the defendant claimed would incrim. inate him. The court held that if answers were compelled under FLA. STAT. $\$ 932.29$ (1951), the defendant would be immune from the abatement suit since it constituted a penalty. Similarly, in Florida St. Bd. of Architecture v. Seymour, 62 So. 2d 1 (Fla. 1952), an architect was deemed immune from loss of his certificate for matters he was earlier compelled to disclose. However, a few states have attempted to define by statute certain consequences of testifying as not constituting a "penalty." Thus, aftcr providing that a witness compelled to testify at an insurance investigation shall thercafter be immunized from prosecution and from "any forfeiture or penalty," Mrar. CoMP. LAws $\$ 500.2033$ (Supp. 1956) states: "Provided, however, That no sucll individual so testifying shall be exempt ... from the refusal, revocation or suspension of any license, permission or authority conferred, or to bc conferred, pursuant to the 
nevertheless confer an immunity from remedial suits. Many of these statutes merely preclude the use of the compelled testimony in civil proceedings; ${ }^{71}$ others expressly grant immunity from civil liability. ${ }^{72}$ Under the Counselman test, all valid immunity statutes must protect the witness from criminal prosecution. Therefore, if the statute immunizing the witness from civil liability does not also protect him from criminal prosecution, it is not a valid basis for compelling testimony. Thus, for example, a statute which simply proscribes the use of testimony in criminal or civil proceedings against the witness would be inadequate. ${ }^{73}$ However, if immunity from criminal prosecution is provided, there would be no federal constitutional objection to a state statute which protected the witness either from civil liability or from the use of the testimony in a civil suit.

Since states are not constitutionally required to provide immunity from remedial suits, the granting of such protection is a mere concession by the state, based on the policy that it is unfair for a witness who is compelled by the state to testify to be subjected to a private suit which he might otherwise not have been forced to defend. Although a degree of unfairness may thereby result to potential plaintiffs where complete immunity from liability is granted, the state's decision may be justified on the ground that the public's need for full and untempered testimony is worth some limitation of the individual's right to civil damages.

\section{Extrajurisdictional Immunity Statutes}

Originally, the possibility of extrajurisdictional use of testimony compelled under the immunity statutes of the state and federal

insurance code." See, e.g., AlA. Code tit. 28, $\$ 90$ (13) (1958); ARR. STAT. ANN. \$66-3014 (1966); Idako Code ANn. $\$ 41-230$ (1961); Mass. Gen. Laws ANN. ch. 176D, 113 (1955).

72 See, e.g., Colo. Rev. Stat. ANn. $\$ 40-9-12$ (1963); Miss. Code ANn. $\$ \$ 1100-01$ (1956); NeB. Rev. StAT. \$32-1114 (1960); N.J. StAT. ANN. \$17:12A-90 (1963); S.D. CodE $\$ 13.2505$ (1939).

72 "But no person who testifies or produces evidence in obedience to the command of the court in such prosecution shall be liable to any suit or prosecution, civil or criminal, for or on account of any transaction, matter or thing concerning which he may so testify or produce evidence; provided, that no person shall be exempted from prosecution and punishment for perjury committed in so testifying." WLs. STAT. ANN. \$325.15 (1958) (emphasis added); see CoNN. GEN. STAT. ANN. \$53-268 (1960); Mich. Compr. Laws $\$ 408.620$ (1948); N.C. GeN. Stat. \$14-354 (1953) (bribery of employees).

${ }^{73}$ For statutes granting immunity only from the use of testimony in criminal or civil proceedings see ArIz. Rev. Stat. ANn. \$41-1223 (1956) and Colo. Rev. Stat. ANN. \$49-18-2 (1963). 
governments was not deemed so substantial a fear as to merit the protection of the privilege against self-incrimination. ${ }^{74}$ However, with the improvement of communications, a few states recognized that a witness compelled to testify ran a substantial risk of extrajurisdictional prosecution on the basis of his testimony. ${ }^{75}$ Thus, state courts in Michigan ${ }^{76}$ and state legislatures in California ${ }^{77}$ adopted rules which would preclude the compulsion of testimony if a significant risk of extraterritorial incrimination would result. The California statute is typical: "[T]he court shall order the question answered or the evidence produced unless it finds that to do so ... could subject the witness to a criminal prosecution in another jurisdiction ...."78 This self-limitation on the states' power to grant immunity operates before the compulsion is applied to the witness. A different approach was taken by Florida, whose statute prohibits the state from conducting a criminal prosecution if such action is based on evidence compelled by another jurisdiction. Thus, the Florida statute provides:

Whenever any witness, after having claimed his privilege against self-incrimination ...., is instructed by order of any court of the United States to testify... involving any interference with ... the national security or defense of the United States .... the testimony or production of evidence of such witness shall not be used as evidence in any subsequent criminal proceedings against him in any court of this state.79

However, regardless of the point at which the state's self-imposed limitation on compulsion of evidence is made, the limitation operates against the state's own interest in acquiring needed information.

After the Supreme Court's decision in Murphy, the fifth amendment itself may be said to contain an extrajurisdictional immunity

\footnotetext{
${ }^{31}$ See Brown v. Walker, I61 U.S. 591, 608 (1896); 8 WiGMORE §2258; note \$1 supra.

${ }^{75}$ See note 37 supra and accompanying text.

${ }^{76}$ People v. Den Uyl, 318 Mich. 645, 29 N.W.2d 284 (1947): " 'We are of the opinion that the privilege against self-incrimination exonerates from disclosure whenever there is a probability of prosecution in state or federal jurisdictions." "Id. at 651, 29 N.W.2d at 287. In State ex rel. Mitchell v. Kelly, 71 So. 2d 887 (Fla. 1954), Den Uyl was cited with approval but was not applied since the claim of federal jeopardy was deemed to be a mere subterfuge.

${ }_{77}$ CAL. PEN. Code $\$ 1324$ (West Supp. 1966).

${ }^{78}$ Id.

${ }^{70}$ FLA. STAT. $\$ 932.291$ (1965). The Florida provision appears to be a legislative codification of the Murphy rule.
} 
provision. ${ }^{80}$ Thus, once a witness has been compelled by one jurisdiction to testify, neither his testimony nor its "fruits" can be used against him in a prosecution by another jurisdiction-state or federal. He may still be prosecuted for a crime disclosed by his testimony if the prosecuting jurisdiction can show the evidence it uses has been acquired from "an independent, legitimate source," and not as a result of the defendant's forced testimony in another jurisdiction. ${ }^{81}$ The immunity provided under the Murphy rule is superior in two respects to state efforts to eliminate the risk of extrajurisdictional incrimination. First, it frees the compelling jurisdiction to require testimony regardless of the fear of subsequent prosecution by another jurisdiction. Secondly, the prosecuting jurisdiction may still prosecute if it can adduce sufficient "independent" evidence. For these reasons, the retention of statutes similar to those of Florida and California constitutes a needless limitation of state power.

However, an addition to the salutary benefits of the Murphy rule, it does create the risk that jurisdictions other than the compelling power will be hampered in the enforcement of their criminal laws. ${ }^{82}$ To avert this possibility, several solutions have been suggested. Where there is a danger that one state's granting of immunity might lessen the chances of conviction under federal law, Congress could, under the necessary and proper clause, require the states to secure the approval of the United States Attorney General before granting immunity to the witness. ${ }^{83}$ However, this suggestion assumes that the Attorney General, an official of the federal government, will be able to determine fairly whether the state's need for information is of less importance than the United States' interest in securing a conviction. A second suggestion, applicable to both the federal-state and to the state-state situations, is for each compelling jurisdiction to require that the state agency conferring immunity must first notify other jurisdictions of the impending compulsion of the witness's testimony. ${ }^{84}$ Once notice is given, other jurisdictions

\footnotetext{
${ }^{80}$ See note 45 supra and accompanying text.

${ }^{81}$ Murphy v. Waterfront Comm'n, 378 U.S. 52, 79 \& n.18 (1964). Of course, the risk of secret, indirect use of compelled testimony still remains. See generally Wendel, Compulsory Immunity Legislation and the Fifth Amendment Privilege, 10 ST. Louss U.L.J. 327 (1966).

82 Singer, State Grants of Immunity-The Problem of Interstate Prosecution Prevention, 58 J. Crum. L.C. \& P.S. 219, 222 (1967).

${ }^{88} \mathrm{Id}$. at 222-23.

${ }^{84} I d$. at 222 .
} 
would be able to inform the compelling jurisdiction of the possible consequences to the interests of those jurisdictions. With this information available, the compelling jurisdiction could then make an informed decision as to whether to grant immunity. Although the possibility remains for the compelling jurisdiction to disregard the interests of other jurisdictions, the Murphy case implies that the choice should reside with the compelling state. This follows from the Court's leaving with the compelling state the decision whether to grant immunity while imposing constitutional limitations on the use of compelled testimony solely on the jurisdiction bringing subsequent prosecution. ${ }^{85}$ A final solution would be that adopted in Oklahoma, which requires that information gained by compulsion be kept secret. ${ }^{86}$ However, there remains the question whether such secrecy can be maintained in face of a federal demand.

\section{Conditions for Statutory Grants of Immunity}

The variety of existent immunity statutes is reflected in the numerous conditions which a witness may have to meet in order to receive statutory protection. Accepting federal constitutional standards, ${ }^{87}$ it might seem that not every immunity grant must encompass the entirety of the fifth amendment privilege against self-incrimination. Despite objections by some courts that any immunity which is not "absolute" 88 will fail constitutional scrutiny, ${ }^{80}$ recognition has

85 "We conclude, moreover, that in order to implement this constitutional rule and accommodate the interests of the State and Federal Governments in investigating and prosecuting crime, the Federal Government must he prohibited from making any such use of compelled testimony and its fruits." 378 U.S. at 79.

${ }^{86}$ OkLa. STat. ANN. tit. 21, §951 (1958).

${ }^{87}$ See Murphy v. Waterfront Comm'n, 378 U.S. 52, 79 (1964); Counselman v. Hitchcock, 142 U.S. 547, 585 (1892); notes $48-49$ supra and accompanying text.

${ }^{88} \mathrm{Much}$ of the difficulty surrounding a determination of the validity of conditional grants of immunity stems from the inexactness of the Counselman requirement that the fifth amendment privilege be replaced only by "absolute" immunity. Similarly misleading is the often-repeated adage that immunity must be co-extensive witl the privilege. Literally interpreted, these phrases would seem to imply that once any aspect of the privilege were invaded by legislation, no limit could exist upon the insulation granted in exchange. In order to be "absolute" in this sense, inimunity could not be restricted to testimony about specific crimes; for any incrimination resulting from otherwise privileged testimony would have to be insulated. Furthcr, a requirement that only subpoenaed witnesses be immunized would fail to provide protection precisely equivalent to that afforded by the fifth amendment. $B u t$ sec notes 94-97 infra and accompanying text. This literalness of interpretation may be supported by language in the Counselman decision: "[L]egislation cannot abridge a constitutional privilege, and . . . cannot replace or supply one, at least unless it is so broad as to have the same extent in scope and effect." 142 U.S. at 585. That such 
been given in both federal ${ }^{90}$ and state $^{91}$ jurisdictions to some forms of restricted immunity grants. Current precedents yield the conclusion that conditional immunity grants are not invalid per se, but may in particular forms lack the co-extensiveness of privilege and immunity contemplated by Counselman. The acceptability of some limitations on statutory protection can be premised on the reasoning that the witness always retains the right to invoke the privilege in lieu of offering a response which has not been legislatively immunized. Further, rather than constituting an overt attempt to restrict the witness's immunity to the constitutional minimum, many statutes, particularly those which limit protection to subjects properly before an administrative agency, ${ }^{92}$ reflect merely a legislative intent to exchange protection only for information which will directly further the particular inquiry and to avoid indiscriminate grants of immunity. However, by conditioning the grant of immunity, states have created a number of interpretative difficulties which arise when a witness responds in reliance upon an offer of immunity made without statutory authorization. ${ }^{93}$ But in many situations where a witness recognizes that a condition to immunity has not been met, the practical effect may be only that the interrogator is deprived of the information he sought.

Procedural requirements. Numerous statutes require that the witness be under oath or subject to subpoena before immunity may be extended. ${ }^{94}$ While testimony given without satisfaction of these

strictness is a misemphasis is suggested by reasonable analysis, i.e., because the witness retains his privilege as to matters which cannot be immunized under a particular statute, he cannot, upon timely claim of the privilege, be subjected to any deprivation as a result of his refusal to testify. Therefore, a more acceptable interpretation of the Counselman language-and one which apparently serves as a basis for restricted immunity grants-would require that no statute compel more testimony than could be insulated by the scope of the immunity authorized.

${ }^{80}$ See, e.g., Lamson v. Boyden, 160 Ill. 613, 43 N.E. 781 (1896); Overman v. State, 194 Ind. 483,143 N.E. 604 (1924).

oo See Cannan v. United States, 19 F.2d 823 (5th Cir. 1927); Comment, 72 Yale L.J. 1568, 1590-91 (1963).

o1 See State v. Chitwood, 73 Ariz. 314, 317, 240 P.2d 1202, 1204 (1952) (dictum); Commonwealth v. Collier, 181 Ky. 319, 204 S.W. 74 (1918).

${ }^{2}$ See, e.g., NEv. REv. STat. \$522.100 (1963); S.D. Code \$42.0708 (Supp. 1960). See also discussion accompanying notes $131-35$ infra.

${ }^{03}$ See notes 132-35 infra and accompanying text.

os Statutes requiring that witness be under subpoena: Colo. REv. STAT. ANN. $\S 80-4-8$ (2) (b) (1963); MINN. Stat. $\$ 30.45$ (1961); N.C. GeN. STAT. §18-8 (1965). Statutes requiring witness to be under oath: DEL. CODE ANN. tit. 26, §187 (1953); IDAFo CODE ANN. \$23-807 (1948); N.J. REv, STAT. §5:8-15 (1959). Statutes requiring that 
conditions may lead to prosecution, their nonexistence will support a respondent's assertion of inapplicability of the immunity statute and, thus, availability of the privilege. However, the existence of the necessary conditions to the immunity grant is frequently difficult to ascertain, especially for the lay witness. An illustration of this dilemma is provided by a 1927 federal circuit court decision having precedential value for state proceedings since Malloy. ${ }^{85}$ Construing a federal statute ${ }^{96}$ which grants immunity only when testimony is offered under oath and pursuant to a subpoena, the court held that answers propounded under oath pursuant to a duly-authorized administrative investigation were not immune from further use, absent formal receipt of a subpoena by the witness. ${ }^{87}$ Thus, when the governing statute is one which does not require a prior claim for immunity to attach, 98 a witness is placed in a somewhat anomalous position of determining whether conditions not within his control have been met. While it can be presumed that deliberate misrepresentations by the interrogator that immunity was available would not meet due process requirements, a much more difficult question is raised-and so far, left without definitive answer ${ }^{00}$ - when the interrogator's negligence or inadvertence has produced a witness's supposition of immunity. ${ }^{100}$

In an attempt to avoid the abuse inherent in a witness's employment of an immunity statute to "cleanse" himself of past crimes with little concomitant benefit to the state, some legislatures have drafted statutes which would confer no immunity to a witness testify-

witness be under either subpoena or oath: MINN. STAT. $\$ 297.09$ (1961); MiNN. STAT. $\$ 297.37$ (1961). Statutes requiring witness to be under both subpoena and oath: Ill. AnN. Stat. ch. 43, §163d (Smith-Hurd 1966); IrL. ANN. STat. ch. 671/2, §278 (Smith-Hurd 1959); Mrch. CoMp. LAws $\$ 462.27$ (1948); Mo. REv. STAT. \$144.340 (1959); N.C. GEN. STAT. \$49-6 (1950).

${ }^{20}$ See notes 24-27 supra and accompanying text.

${ }^{96}$ Federal Trade Commission Act $\$ 10,15$ U.S.C. $\$ 49$ (1964).

${ }^{97}$ Cannan v. United States, 19 F.2d 823 (5th Cir. 1927). See also Sherwin v. United States, 268 U.S. 369 (1925).

${ }^{88}$ See note 50 supra.

${ }^{90}$ In State v. Chitwood, 73 Ariz. 161, 239 P.2d 353 (1951), modified, 73 Ariz. 314, 240 P.2d 1202 (1952), a witness had not been advised as to the point in the questioning after which immunity would no longer attach. Without attempting to cvaluate whether the interrogator's omission was deliberate or negligent, the court was willing to extend immunity to testimony which was not specifically immunized by the statute. Accord, Overman v. State, 194 Ind. 483 , 143 N.E. 604 (1924).

${ }^{100}$ See notes 132-36 infra and accompanying text. 
ing because of his own "procurement or contrivance."101 It would appear that this condition could qualify either the voluntariness of the testimony or the occasion of the witness's appearance before a body which could grant immunity. To interpret the language to mean that immunity is not available for voluntary, noncompelled testimony does not violate fifth amendment standards, for the privilege attaches only to compulsorily-procured testimony. ${ }^{102}$ Mississippi, however, has interpreted its statute to grant immunity without regard to the voluntariness of enunciations as long as the witness's appearance has not been the result of his own manipulations. ${ }^{103}$ This analysis, while granting an immunity more extensive than that demanded by fifth amendment precedents, avoids the necessity for a judiciary to delve into the question of the witness's subjective motivations at the time of his appearance.

Testimonial verity. Those statutes which grant immunity only when the witness testifies "truthfully" or "fully and without reserve" apparently reflect the simplistic legislative intent that the state will forego its right of prosecution only if it has received reliable information. ${ }^{104}$ It is established that the statutory immunity does not insulate against prosecution for perjury unless explicitly indicated in the enactment. ${ }^{105}$ Constitutional standards probably are not met, however, if untruthfulness as to certain aspects of one's testimony is employed as a basis for withdrawal of immunity for other utterances. Since the fifth amendment privilege is granted to any statement which may provide a segment of the evidential development of proof of criminality, ${ }^{106}$ and since such privilege can be avoided only

\footnotetext{
${ }^{101}$ See, e.g., ARk. Stat. ANN. §6-815 (Supp. 1965); Miss. Code ANn. §3337 (1956); Miss. CODE ANN. \$3365-08 (1956).

${ }^{109}$ See 8 WIGMORE $\$ 2282$, at 514 .

${ }^{103}$ See State v. Billups, 179 Miss. 352, 174 So. 50 (1937).

${ }^{104}$ Statutes requiring the witness to testify truthfully: e.g., ArA. CODE tit. 17, $\$ 233$ (1958); Tex. Rev. Crv. Stat. Ann. art. 7446 (1960). Statutes requiring the witness to testify fully and without reserve: e.g., Fla. Stat. \$542.11 (1965); ORLA. Stat. ANN. tit. 21, §391 (1958); Tex. Pen. Code ANn. art. 1621 (1953).

${ }_{105}$ See Glickstein v. United States, 222 U.S. 139 (1911); People v. Berger, 197 Misc. 915, 100 N.Y.S.2d 278 (Sup. Ct. 1950); State v. Ingels, 4 Wasli. 2d 676, 104 P.2d 944, cert. denied, 311 U.S. 708 (1940). Many statutes expressly exempt prosecutions for perjury from the grant of immunity. E.g., UTAF CoDE ANN. \$34-1-1I (1966); VA. CODE ANN. $\$ 60-38$ (1949); WASH. REv. CODE $\$ 49.60 .150$ (1958). See also Chitwood v. Eyman, 74 Ariz. 334, 248 P.2d 884 (1952).

${ }^{100}$ See Hoffman v. United States, 341 U.S. 479, 486-87 (1951); Blau v. United States, 340 U.S. 159, 161 (1950); Falknor, Self-Crimination Privilege: "Links in the Chain," 5 VAND. L. Rev. 479 (1952).
} 
by respondent's waiver or a grant of immunity, ${ }^{107}$ to allow prosecution on otherwise protected testimony accompanying perjured utterances amounts to an equation of partial falsehood with waiver, a conclusion unsupported by even vague precedential implications. Further, availability of prosecution for perjury would seem to provide a sufficient remedy when the legislative desire for reliable information is frustrated: the unperjured portion of a witness's testimony may have no significantly diminished utility to the state merely because of accompanying untruthfulness. ${ }^{108}$

While vagueness inherent in a statute drafted with immunity seemingly conditioned upon the truthfulness of the testimony raises a substantial difficulty, it has been avoided in at least one jurisdiction by perceptive judicial interpretation. In Ferrantello v. State, ${ }^{100}$ the Court of Criminal Appeals of Texas reasoned that since a witness testifying under oath is required to respond accurately, the language of the immunity statute could be given no independent effect. This failure to find the statute's immunity conditional led to the conclusion that the statutory protection did comport with the constitutional requirement that it be co-extensive with the privilege against self-incrimination.

Qualification of the grantee. While many immunization statutes state that "no person" may invoke the self-incrimination privilege against demanded information, either in the from of testimony or documents, these same statutes generally shield only a "natural person" from prosecution on the basis of such evidence.110 According

\footnotetext{
${ }^{107}$ See Counselman v. Hitchcock, 142 U.S. 547 (1892).

${ }^{108}$ If truthful portions of a witness's testimony are used to discover non-verbal evidence against other parties, the value of his testimony would seem undiminished by the existence of perjured portions. If the witness's verbal implication of another participant were introduced at a subsequent trial, however, the use of earlier perjured testimony to attack the informer's creditability would, of course, significantly lessen his utility in securing a conviction.

${ }^{109} 158$ Tex. Crim. 471, 482, 256 S.W.2d 587, 595 (1952).

120 See, e.g., Fra. STAT. \$ 377.32 (1965); IrL. ANN. STaT. ch. 5, \$158 (Smith-Hurd 1966); Minn. Stat. \$30.45 (1961); Neb. Rev. Stat. \$57-912 (l) (1960).

Conceivably, such statutes might be interpreted to deny immunity to individuals altogether on a rationale similar to that utilized by the Supreme Court in Shapiro v. United States, 335 U.S. I (1948). In that case a federal immunity statute granted prosecutorial protection to those who produced records or testified in an investigation of price-ceiling violations. Reasoning that since Congress had required such records to be kept for the purposes of regulation and enforcement, the Court held that no privilege existed as to the inculpatory material and thus the immunity provisions were inapplicable. $1 d$. at 22-25. In a similar manner, a state court might reason that because an individual has no privilege against the production of inculpatory organiza-
} 
to traditional constitutional doctrine, an organization, particularly a regulated economic form, is not a "natural person"111 within the terms of fifth amendment applications. Thus, neither the group nor its agent-officers may invoke the privilege against the production of incriminatory associational records. ${ }^{112}$ At the same time, organizational officials have retained protection against compulsory oral testimony. ${ }^{113}$ Consequently, if these statutes extend immunity to a "natural person" who produces incriminatory organizational records, the protection granted to the individual officer is greater than that afforded by the Federal Constitution. However, even though an organization can act only through such protected individuals, the entity itself remains vulnerable because of the statutory phrasing. Language in several statutes that inculpatory protection will not be granted to specified industrial or service corporations arguably leaves a negative implication of general organizational immunity. ${ }^{114}$ However, these statutes do not contain the "natural person" limitation in the immunity grant, but rather state that "no person" shall be prosecuted on the basis of the compelled disclosure. Thus, it seems clear that by specifically denying incriminatory protection to the investigated organization, these states merely utilized an alternative method to grant immunity to "natural persons" only.

Immunity conditioned on fear of a specific kind of incrimination. Both the wisdom and the constitutionality of one variety of state immunity statute may be questioned. Such a statute typically grants immunity from any incrimination if the witness is compelled to testify after asserting a fear of a specific kind of incrimination. Michigan's provision compelling testimony of a witness in the investigation of a judgment debtor's affairs provides an example:

tional records, the immunity grant is insufficient to prevent his prosecution. See id.; Wilson v. United States, 221 U.S. 361 (1911). But see Note, 1968 DukE L.J. 134. ${ }_{211}$ Wilson v. United States, 221 U.S. 361 (I9II); Hale v. Henkel, 201 U.S. 43 (1906) (corporate officer cannot raise privilege against testifying to acts of corporation or producing its records because protected by immunity statute); cf. United States v. White, 322 U.S. 694 (1944) (identifying "natural" as "personal" but allowing "personal" groups to invoke the privilege). But cf. Shapiro v. United States, 335 U.S. 1 (1948) (individuals required to keep regulatory records may not invoke privilege with respect thereto).

${ }^{122}$ See cases cited note 111 supra. But cf. Communist Party v. United States, 389 F.2d 957 (D.C. Cir. 1967); Note, 1968 DukE L.J. 134.

${ }^{213}$ See Curcio v. United States, 354 U.S. 118 (1957).

${ }^{114}$ See, e.g., CaL. Pub. UtIL. Code $\$ 1795$ (West 1956); HawaIr Rev. Laws. $§ 104-9$ (1955); IDAHO CODE ANN. $\$ 61-606$ (1948). 
A party ... may not be excused from answering a question on the ground that his answer will tend to show him guilty of the commission of a fraud.... But an answer cannot be used as evidence against the persons so answering in any criminal proceeding or action. ${ }^{115}$

Since statutes like the Michigan provision usually preclude the use of compelled answers against the witness, they would be invalid under the Counselman test, as well as under the constitutions of many states. ${ }^{110}$ However, should a state choose to incorporate into this type of statute an immunity from prosecution, as Kansas has done, ${ }^{117}$ the Counselman standard would be satisfied.

However, assuming the constitutionality of such an immunity statute, and acknowledging that its enactment was an attempt to limit the granting of immunity solely to situations where the privilege is especially apt to thwart the particular investigation, a definite question as to the statute's ability to serve state interests remains. On the one hand, should the witness claim, either in good or bad faith, that he fears his answers will incriminate him in the manner specified by the statute (i.e., for fraud), he will be immunized from prosecution for any crimes disclosed, including those not under investigation, even if they do not involve fraud. As a result, more crimes may be immunized than is necessary. Moreover, there is virtually no way that the state can minimize the risk of this result by inquiry beforehand as to the witness's good faith in claiming his fear of fraud, without probing into the very matter the privilege is designed to protect. On the other hand, if the witness claims he fears incrimination for a crime different from that specified by the statute, the state lacks the power, by virtue of the conditional nature of the statute, to immunize the witness and thereby to destroy his basis for asserting the privilege against self-incrimination. This produces a complete

\footnotetext{
${ }^{116}$ Mrch. Comp. Laws $\$ 600.6110$ (Supp. 1961) (emphasis added); sec ConN. Gen. Stat. Rev. \$52-398 (1958); MONT. ReV. Codes ANN. \$93-5909 (1964); S.C. Code ANN. § 10-1723 (1962); WASH, REV. CODE §6.32.200 (1956).

${ }^{120}$ See notes 62-64 supra and accompanying text.

${ }^{217}$ KAN. GEN STAT. ANN. \$21-943 (1964) provides: "No person shall be incapacitated or excused from testifying touching any offense committed by another against [gambling laws] ... by reason of having participated in any prohibited games or played at or with any gambling device prohibited by the laws of the state of Kansas, but no person shall be prosecuted or punished on account of any transaction, matter or thing concerning which he may be so required to testify or produce evidence ...." (emphasis added).
} 
frustration of the state's purpose in enacting the statute-to acquire needed information. Again, no state inquiry into the basis of the witness's assertion that he fears incrimination in a way other than specified by the statute is possible.

Immunity grants conditioned on subsequent occurrences. Because the fifth amendment privilege is absolute in the sense that no prosecution can result from compelled incrimination, ${ }^{118}$ an attempt to condition immunity upon occurrences subsequent to its having been given is contrary to constitutional mandates insofar as the witness must endure the possibility of future prosecution. Shortly after the Counselman decision, states began re-evaluating their immunity statutes to eliminate phraseology which might provide an insulation against prosecution less pervasive than that demanded under the fifth amendment. In the exemplary decision of Lamson v. Boyden, ${ }^{\mathrm{I} 11}$ the Supreme Court of Mlinois declared unconstitutional the immunity provision of a statute prohibiting "cornering" in grain markets. Under this statutory scheme, immunity was granted when certain disclosures were made, provided profits received by the witness through market manipulation were relinquished. ${ }^{120}$ Quoting Counselman language, the court stated that the immunity statute "is unconstitutional unless it affords 'absolute immunity against future prosecution for the offense to which the question relates." "121 Under the Mlinois court's interpretation, the utterance of incriminating evidence alone was sufficient to immunize the witness against any form of prosecution by the state. To require, in addition, the subsequent relinquishment of profits was to impose a condition making the immunity less than "absolute."

Though this reasonable interpretation of Counselman is applicable to any statute which would condition immunity upon occurrences subsequent to incrimination, an Oklahoma election bribery provision, ${ }^{122}$ which has counterparts in other jurisdictions, ${ }^{123}$

\footnotetext{
${ }^{118}$ Such is the current intrajnrisdictional implication of the fifth amendment. See text following note 47 supra. 110160 III. 613, 43 N.E. 781 (1896).

${ }^{130}$ An Ohio statute attempting to encourage restrictions of gambling winnings remains in force. Orro REv. Code ANN. $\$ 3763.05$ (Page 1954).

${ }^{121} 160$ Ill. at 620,43 N.E. at 783.

122 Orla. Stat. ANN. tit. 26, $\$ 446$ (1955).

${ }^{120}$ See, e.g., N.H. Rev. Stat. ANN. \$69:28 (1955). See also Ky. REv. STAT. \$124.330 (1962); LA. Rev. Stat. §14:12I (1950); Mich. CoMp. LAws §750.125 (1948).
} 
would under some interpretations immunize only upon procurement of a conviction pursuant to compelled information. The questionable validity of the statute is compounded by confusing drafting. The first sentence of the statute provides that a witness may be compelled to testify but that any testimony elicited will not be used in a subsequent prosecution against the witness; a second sentence allows immunity from prosecution for one "who voluntarily discloses . . . evidence . . . and procures a conviction ...."

If the stricter Counselman standard were applicable, ${ }^{124}$ both provisions would fail constitutional scrutiny: the first for its failure to immunize against prosecution and the latter because it would allow prosecution in instances in which disclosure did not lead to successful prosecution of one other than the witness. Under the Murphy criterion, ${ }^{125}$ the statute as a whole would be valid, since a witness testifying pursuant to any form of compulsion could be immunized from future use of any incriminating statements by application of the general provisions of the first sentence. The conditional immunity from prosecution provided by the second provision simply seems a legislative extension of immunity not compelled by the fifth amendment but enacted to give state agencies more power to bargain for information. Its conditional nature would not be subject to a fifth amendment challenge because the statute's protection could, under no circumstances, fall below the constitutionally valid immunity-from-use provision. However, the latter sentence might give rise to frequent due process objections if it were invoked against a witness who did not give evidence leading to prosecution but whose testimony was elicited pursuant to an assurance of immunity or other indicia sufficient to produce the type of compulsion contemplated by the fifth amendment. ${ }^{126}$ The potential interpretative difficulties of the Oklahoma statute are avoided by careful drafting in a similar Louisiana provision. ${ }^{127}$ This latter statute makes it clear that a grant of immunity from prosecution is a supplemental measure to be employed at the district attorney's discretion in situations in which complete immunity might ensure fuller disclosure of illegal transactions.

The grant of immunity from prosecution clearly reflects a legis-

\footnotetext{
${ }^{124}$ See text accompanying note 48 supra.

125 See notes 38-42 supra and accompanying text.

126 See 8 WIGMORE $\$ 2282$, at 514.

127 I,A. REV. STAT. $\$ 14: 121$ (1950).
} 
lative intent to encourage revelation of illegal transactions by one perpetrator of a multi-party crime, such as bribery, which lacks manifestations which would be readily identifiable by investigating officials. ${ }^{128}$ While such facilitation of investigations is desirable, conditioning immunity upon procurement of a conviction-or as in other statutes, upon the "tendency" of the testimony to incriminate another ${ }^{129}$-may produce unjustifiable practical results. Whether conviction of another results from testimony depends on a myriad of contingencies beyond the control of the witness. For example, the anticipated insulation may be lost because of a prosecutor's decision not to pursue a conviction. ${ }^{130}$ It might also be argued that this conditional grant of immunity lacks fairness to the person eventually prosecuted. Thus, the prospective informer is placed in a position of having to anticipate the resolution of an untried prosecution, and, in order to ensure his immunization, he may either present perjured testimony or fail to relate exculpating facts. Moreover, contrary to its intended result, the contingent immunity statute tends to promote less than full disclosure since participants in a crime who know factors which would limit the defendant's criminal liability are given no impetus to volunteer their evidence. The defendant's disadvantage could be equalized in many situations, however. Assuming the identity of witnesses possessing such exculpatory information can be made known to a prosecutor, their testimony could be compelled under those statutes, such as the Oklahoma provision discussed above, which provide general immunity from subsequent use of incriminating testimony.

The requirement of pertinency. A provision adopted in several states for furthering administrative investigations restricts immunity to responses which are "pertinent to some question lawfully before such commission ...."131 The legislative purpose in enacting such a provision is apparent; i.e., any matter which would not promote the particular investigation would be of little or no value to the

${ }^{128}$ See Reporter's Comment, LA. REv. StaT. ANN. \$14:121 (1951).

${ }^{120}$ See, e.g., Mrch. CoMp. LAws $\$ 750.125$ (1948).

${ }^{180}$ To make a grant of immunity depend upon such factors as the adequacy of the prosecutor's preparation for the trial of the implicated party or his post-arrest treatment is, of course, to effectively discourage fullest cooperation on the part of the informer.

${ }_{131}$ N.M. Stat. AnN. \$64-27-80 ( $t$ ) (Supp. 1967). See also Fla. Stat. \$377.32 (1965); NEv. REv. STAT. \$ 522.100 (1961); N.D. CENT. CODE § 38-08-12 (1960); S.D. CODE $\$ 42.0708$ (Supp. 1960). 
state and absent receipt of some benefit, the government should not forego its power to prosecute, an affront to its criminal statutes. In its most common format, this type of immunity statute is introduced by a statement that the privilege against self-incrimination may not be invoked. This broad assertion is then tempered by preservation of the fifth amendment privilege for impertinent matters. Finally, immunity against prosecution is granted for any matter revealed which is pertinent. Thus, when a witness refuses to respond to a question which is clearly irrelevant, he seems to be within the exemption from compulsion intended by the legislature. In situations involving inquiries which are less clearly unrelated to the scope of an agency's investigatory powers, the witness faces a dilemma: if he refuses to answer, he must endure a possible contempt citation; ${ }^{132}$ if he answers and the question is not relevant to the body's investigation, he may find himself outside the scope of the statute's immunization. A similarly difficult question is raised when a witness testifies without contesting the pertinency of the particular inquiry and claims immunity at a subsequent prosecution based on incriminating, though irrelevant, revelations. Since he could not have been compelled to make such disclosures, the prosecutor may argue, he was not entitled to fifth amendment protection as to their substance. In the absence of a claim of the privilege, the witness might now be deemed to have waived his right against self-incrimination. A further basic objection to a requirement of pertinency is that it places on the witness the tremendous burden of relating a specific question to all matters under the general consideration of the investigating agency. Not only would the layman have to ascertain the outline of subjects touched on by other witnesses, but he would also have to assure himself of the statutory authorization for every aspect of the investigation. Even assuming the ability of the witness to isolate the proper considerations, he would bear the risk of misjudging the pertinency of the particular inquiry.

Judicial relief from these dilemmas might be obtained under precedents in an analogous area. Several courts have held that a witness who has testified under a statute which immunizes for only specific crimes can prevent, in a subsequent prosecution, the use

${ }^{132}$ Cf. State v. Chitwood, 73 Ariz. 161, 170, 239 P.2d 353, 359 (1951), modified, 73 Ariz. 314, 240 P.2d 1202 (1952). 
of testimony as to unrelated violations by virtue of the continuing efficacy of the fifth amendment as to non-immunized offenses. ${ }^{133}$ However, without attempting to delineate this conclusion in terms of fifth amendment or state constitutional mandates, judicial recognition has been given to the difficulty encountered by a defendant in attempting to ascertain whether a particular revelation furthers the investigation of a crime to which immunity attaches or whether his particular response advances the inquiry beyond protected limits. ${ }^{134}$ At least one court has found immunization necessary because of the possibility that the interrogator may, either intentionally or by inadvertence, bear responsibility for leading the witness into unrelated areas. ${ }^{135}$

Under a statute which requires the witness to claim his privilege against self-incrimination before immunity will be granted, the issue of pertinency may lose some of its significance, since it might be legitimately argued that a failure to raise an appropriate objection amounts to a waiver of the constitutional privilege. Such a proposition, however, provides an unsatisfactory resolution when the interrogator has in any manner produced a witness's assumption that his incriminatory statements could not be employed in a subsequent prosecution against him. It would seem preferable to place upon the interrogator some responsibility for specifying the limits of the statutory immunity grant, particularly if he has, as is usually the case, prefaced his questioning with an explanation of the witness's duty to testify.

\section{Conclusion}

Since the 1964 decisions in Malloy and Murphy have dictated the invalidity of many of the existent immunity provisions, it might be assumed that intensive legislative re-evaluations would have taken place subsequent to those pronouncements. Evidence of corrective undertakings is, however, almost nonexistent. Perhaps the

\footnotetext{
${ }^{188}$ See State ex rel. Mitchell v. Kelly, 71 So. 2d 887 (Fla. 1954); cf. Overman v. State, 194 Ind. 483, 143 N.E. 604 (1924).

184 State v. Chitwood, 73 Ariz. 161, 170, 239 P.2d 353, 359 (1951), modified, 73 Ariz. 314, 240 P.2d 1202 (1952).

${ }^{185}$ Id. But of. United States v. Ford, 99 U.S. 594 (1879); United States v. J.R. Watkins Co., 127 F. Supp. 97 (D. Minn. 1954); People v. Indian Peter, 48 Cal. 250 (1874).
} 
failure of the Supreme Court to reassess the current applicability of the Counselman precedent can be isolated as a partial cause of this inaction. Nonetheless, questions substantially unaffected by Counselman, such as the need for extrajurisdictional immunity grants, would seem to deserve current attention.

When legislatures commence the necessary reconsideration, an opportunity would be afforded for a thorough restructuring of a statutory framework. A single, all inclusive immunity provision might then replace the current piecemeal approach to satisfaction of constitutional standards. Since the old system of grants limited to specific investigations has presented inconsistent phrasing which precludes meaningful ascertainment of legislative intent, implementation of a central immunity statute could eliminate many interpretative difficulties. Absent such a radical alteration, the several hundred immunity statutes will be open to individual constitutional evaluations by both federal and state courts. 